\title{
Religious Courts in Indonesia in Troubled Financing Settlement of Islamic Banks during the Covid-19 Pandemic
}

\author{
Hermin Sriwulan, S.HI, SH, M.HI \\ Religious Court Judge Magelang, Central Java, Indonesia. \\ Student of Legal Studies doctoral program at the University of Brawijaya, Malang, East Java-Indonesia
}

\begin{abstract}
Based on the Law Number 3 of 2006 concerning Amendments to Law Number 7 of 1989 concerning the Religious Courts, it shows that the Religious Courts in Indonesia have the authority to resolve sharia economic disputes. Therefore, Religious Court Judges must continue to improve their capabilities in this field because in the midst of the Covid 19 disaster that also hit Indonesia, creditors often argue that a force majeure / overmacht has occurred so that it allows for a spike in disputes in the economic and business world, including Islamic banking. Although basically this situation is not an overmacht, it is a difficult situation / masyaqqah. On the other hand, finally the POJK regulation Number 11 / POJK.03 / 2020 concerning National Economic Stimulus as a Policy on the Countercyclical Impact of the Spread of Corona Virus Disease 2019, by providing the policies in the form of restructuring, credit relief, or new funding for debtors who are indeed affected by Covid 19, has led to multiple interpretations among creditors. Even though the losses caused by Covid 19 can be guaranteed by the government. As in Permenkeu number 71 / PMK.08 / 2020 concerning Government Guarantee Procedures through Guarantee Business Entities Designated in the Context of Implementing the National Economic Recovery Program, however, if a dispute occurs in litigation, the judge must be careful in making decisions.
\end{abstract}

Keywords: Role of Religious Court, the dispute Islamic banks, pandemic covid 19

DOI: $10.7176 / \mathrm{JLPG} / 102-04$

Publication date:October $31^{\text {st }} 2020$

\section{Introduction}

Religious Courts in Indonesia are part of the four pillars of justice under the Indonesian Supreme Court besides the General Courts, State Administrative Courts and Military Courts. The Religious Courts are part of government activities in order to uphold justice through judicial powers under the auspices of the Supreme Court. Religious Courts are Islamic courts in Indonesia, which try Muslims and cases in which the contracts use Islamic or sharia contracts. Based on the types of cases under its authority in adjudicating cases, all of them are based on Islamic law. It can be concluded that the Religious Court is one of the legal Indonesian state courts, which is a special court, which is authorized in certain types of Islamic cases as referred to Law Number 50 of 2009 concerning the Second Amendment to Law Number 7 of 1989 concerning Judiciary Religion, for Muslims in Indonesia. ${ }^{1}$

The absolute authority of the Religious Courts or what is often referred to as absolute competence is as stated in article 49 of Law Number 50 of 2009 concerning the Second Amendment to Law Number 7 of 1989 concerning the Religious Courts, which states that the Religious Courts have the duty and authority to examine, decide, and settle cases at the first level between people who are Muslim in the fields of marriage, inheritance, wills, grants, waqf, zakat, infaq, shadaqah and sharia economics. Then the authority was added again based on Article 15 paragraph (2) of Law Number 4 of 2004 concerning Judicial Power and also Article 3 Paragraph (1) of the Presidential Decree No. 11 of 2003 concerning the Syar'iyah Court and the Provincial Syar'iyah Court in the Province of Nanggroe Aceh Darussalam. It shows that the Religious Courts have the authority to handle and decide special jinayah cases in the Aceh region.

One of sharia economic activities is sharia banking. With its various product variants, Islamic banking has brought its own legal implications. Especially after several disputes arose for the parties involved in it. If the banking dispute is unable to find a solution or settlement in mediation or arbitration, the settlement will be through court / litigation. Courts are used as a place to seek justice and resolve legal issues that arise, besides the alternative non-litigation solutions that exist in Indonesia. ${ }^{2}$

The outbreak of the corona virus or known as Covid-19 has shattered order all the fields including the economies of almost all countries in the world. According to most researchers and economists in the world, this epidemic is considered to be the cause of the worst global financial crisis when compared to the Asian financial crisis in 1997-1998, or the subprime mortgage crisis in 2008. ${ }^{3}$ Many business sectors suffered losses as a result of the Covid 19 disaster. Obligations / achievements that should be carried out by debtors to Islamic banks as creditors are constrained and even stuck, this is a big potential for an increase in disputes over problematic financing that

\footnotetext{
${ }^{1}$ CST Kansil and Christine STKansil. Hukum Tata Negara Republik Indonesia. (Jakarta: Rineka Cipta, 2008$)$, p. 161.

${ }^{2}$ A. Mukti Arto, Mencari Keadilan. (Yogyakarta: Student Library, 2001), pp. 12-13.

${ }^{3}$ https://republika.co.id/berita/q9tijc320/peranggung-syariah-face-covid19-tantangan-dan-solusi, accessed on 15 August 2020.
} 
occur between Islamic banks and their customers as a result of the Covid 19 outbreak.

Sharia economic disputes registered in the Court Religion in Indonesia has increased in quantity from year to year. In 2016 there were 229 sharia banking disputes in the Religious Courts, then in 2018 they increased to 287 cases, and 312 cases in total in 2019

Thus, with the covid 19 disaster that hit Indonesia from all aspects of life, especially from the business and economic aspects, of course it can have the effect of triggering significant disputes in business activities based on sharia contracts.

In response to this, the Religious Courts have a strategic role not only in resolving issues of sharia economic disputes in order to create legal certainty, but also in efforts to ensure the safety of court officials and the safety of the people as the highest law of a country (Salus populi suprema lex esto) from the Covid 19 virus outbreak that is increasingly widespread throughoutarchipelago region.

\section{Discussion}

\subsection{Definition of Sharia}

Economics Sharia economics or Islamic economics is not a part of the science of belief, but generally it constitutes assumptions, because of its position which is part of the results of taking general arguments about economics, ahad hadiths, standard estimates or the like. ${ }^{1}$

The definition of Islamic economics was also put forward by Umar Chapra, which is ${ }^{2}$ defined as a branch of knowledge that helps to realize human welfare through an allocation and distribution of natural resources in accordance with maqashid without restricting individual freedom to create sustainable macroeconomic and ecological balance, forming solidarity, family, social and community networks.

There are many more experts who provide definitions of what Islamic economics is. In general, Islamic economics can be defined as a Muslim individual behavior in every Islamic economic activity that must be in accordance with the demands of Islamic law in order to realize and maintain the maqashid of Sharia (religion, soul, reason, lineage, and property). ${ }^{3}$

In the context of the application of economic activities in Indonesia, Islamic Economics is known as Sharia Economics. Sharia economics ${ }^{4}$ is a business or activity carried out by an individual, a group of people, a business entity that is either a legal entity or not a legal entity in order to meet commercial and non-commercial needs according to sharia principles. ${ }^{5}$

Sharia economics which is the authority of the Religious Courts can be reviewed based on the explanation of Article 49 letter i of Law Number 3 of 2006 concerning the Religious Courts. It is explained that;

"What is meant with Sharia economics is an act orbusiness activities carried out according to Sharia principles including: a. Islamic Bank; b. Sharia microfinance institutions; $c$. Sharia insurance; $d$. Sharia reinsurance; e. Sharia mutual funds; $f$. Sharia medium-term bonds and securities; g. Sharia securities; h. Sharia financing; $i$. Sharia pawnshops; j. Pension funds for Sharia financial institutions; and k. Sharia business."

\subsection{Sharia Economic Law in the Legal Order in Indonesia}

Islamic law is one of the sources of national law along with western law and customary law, it does not mean that it has to be formal law with its own exclusive form, except for its nature to serve (not impose imperatively) on what already applies. as awareness in everyday life. Here the source of law must be interpreted as a material source of law in the sense that it becomes the content material for a source of formal law. Moreover, Islamic law has long had a place in Indonesia in the context of its long existence, both normatively, sociologically and juridically.

According to Amin Summa, the most important reason for the application of Islamic law in Indonesia isthe reason of constitution and the reason of historyas well as the reasons for the need for Islamic law itself.

Even though the formation of national law that is based on the teachings of sharia cannot be separated from the context of national legal politics, but in the framework of practicing Islamic teachings in a kaffah (perfect) manner $^{6}$, Islamic law legislation is placed in the framework of the needs of the Muslims themselves. Therefore, the law is carried out consistently, because it is considered a form of practicing true Islamic teachings even in the form of statutory regulations. In addition the theory of acceptance of legal authority (creed theory) emphasizes

\footnotetext{
${ }^{1}$ Abdullah Abdul Husain at-Tariqi, Ekonomi Islam Prinsip, Dasar dan Tujuan, (Jakarta: Magistra Insania Press, 2004), first published, September, p. 1.

${ }^{2}$ M. Umar Chapra, The Future of Economies: an Islamic Prespective,(Jakarta: SEBI, 2000), p. 25.

${ }^{3}$ M. Nur Rianto Al Arif, SE, M.Si, Teori Ekonomi Islam ,(Jakarta: ALFABETA, 2010), first published, p. 40).

${ }^{4}$ Article 1 number 1 KHES (Compilation of Sharia Economic Law), PERMA No. 2 of 2008, 10 September 2008;

${ }^{5}$ Article 4 paragraph (3) of Law no. 1 year 2016 regarding Guarantee, states that the principles of sharia are business activities that do not contain the following elements: riba,, maisir, gharar, haram, and zalim

${ }^{6}$ MA. Mannan said there are seven basic reasons for the existence of Islamic economics, namely: ideological, economic, social, ethical, political, historical, and international. See: MA. Mannan, The Making of Islamic Economic Society (Cyprus: International Association of Islamic Bank Cairo \& Institute for Islamic Banking and Economic, 1984), p. 3-19.
} 
that Islamic law confirms that everyone and anyone who has declared himself a Muslim, by saying two sentences of sahadat, he is bound to submit to Islamic law and teachings. Because after all, so that the implementation of legislation aimed at reform can run properly, it should be in accordance with the laws that live in society. This is in line with NJ Coulson's view that law always lives and develops in line with the rate of development of a society.

The presence of sharia economic law in the Indonesian legal system today is no longer just due to historical and demographic demands (because the majority are Muslim) but also due to the needs of the wider community once it is known and felt correctly, how fair and even the syariah economic system is in safeguarding the people's welfare, which the nation and the Unitary State of the Republic of Indonesia aspire to. This is in line with the development of society that is increasingly critical about the investment mechanism with a profit and loss sharing system that is implemented and has a better impact.

The legal position of Islamic / sharia economics as described above will be stronger when it is linked to the philosophy and constitution of the state, namely Pancasila and the 1945 Constitution of the Republic of Indonesia. In short, the Islamic economic system is not at all contradictory and violates Pancasila, especially the "Divine Precepts Which Almighty, "also not at all contradicting, against the Constitution of the Republic of Indonesia, both in the Preambule which includes the sentence: "...By realizing a social justice for all Indonesian people, "as well as with its contents especially as stated in CHAPTER XI (Religion) Article 29 paragraph (1) and (2), as well as CHAPTER XIV Articles 33 and 34 which govern the national economy and social welfare of Indonesia.

National Law is a law that applies to certain nations in a certain national state. In the case of Indonesia, national law is the law developed by the Indonesian nation after independence and applies to Indonesian citizens, especially citizens of the Republic of Indonesia, as a substitute for colonial law. In short, national law is the law that applies after the Indonesian nation's independence for the national interest, based on Pancasila and the 1945 Constitution, which applies to citizens of the Republic of Indonesia. ${ }^{2}$ In line with the above definition, according to Amir Syarifuddin, national law is a set of written rules regulating the level of human behavior, made and carried out by a determined state body, applicable and binding for all Indonesian citizens. ${ }^{3}$

The birth of Law Number 3 of 2006 concerning Amendments to Law Number 7 of 1989 concerning the Religious Courts, which was then followed by the issuance of Law Number 21 of 2008 concerning Islamic Banking, Law Number 19 of 2008 concerning National Sharia Securities ( SBSN or Sukuk), Law Number 23 Year 2011 regarding Zakat Management and so on, this shows that Sharia Economic Law in Indonesia has become a national law (positive law) in the legal system in Indonesia. It is sharia economic law which is a product of the Indonesian nation sourced from the 1945 Constitution and Pancasila that is valid and binding for all Indonesian citizens.

\subsection{Authority of Religious Courts Over Sharia Economic Disputes}

The basic principles of sharia economic contracts in Islamic banking are based on the Koran and the Sunnah. After a deeper examination of the basic philosophy of the operation of a Sharia Bank which animates all transaction relationships based on three things, namely efficiency, fairness, and togetherness. Efficiency refers to the principle of helping each other synergistically to obtain the greatest possible profit / margin. Justice refers to a relationship that is not rigged, sincere, with mature agreement on the proportion of inputs and outputs. Togetherness refers to the principle of offering mutual assistance and advice to increase mutual productivity. ${ }^{4}$

According to Mukti Arto, there are two principles for determining the absolute competence of a religious court, namely: First, if a case concerns the legal status of a Muslim, and / or second, a dispute arises from an act or legal event that is carried out or occurs based on Islamic law or closely related to the legal status as a Muslim. ${ }^{5}$

This is based on the fact that the legal relationship that occurs between legal subjects based on sharia principles will give birth to legal consequences, of course the settlement process is also based on sharia principles. Meanwhile, the only court that has the authority to apply sharia principles and make the Koran, the Hadith of the Prophet, and the ijtihad of Islamic jurists as guidelines for proceeding in the judiciary is only the Religious Court.

The legal basis for the absolute authority of the Religious Courts in Article 49 of Law Number 3 of 2006 concerning Amendments to Law Number 7 of 1989 concerning the Religious Courts which states that the Religious Courts have the duty and authority to examine, decide, and resolve cases at the first level between persons who are Muslims in the fields of marriage, inheritance, wills, grants, waqf, zakat, infaq, shadaqoh, and sharia economics. This is also in line with Article 55 of Law Number 21 of 2008 concerning Sharia Banking which clearly states that:

\footnotetext{
${ }^{1}$ Abdul Halim, Peradilan Agama Dalam Politik Hukum di Indonesia dari Konservatifmenuju Konfigurasi Demokrasi-Responsif, (Jakarta:Raja Grafindo Persada, 2000), p.1.

${ }^{2}$ Mohammad Daud Ali, "Pendidikan Syari" at dalam Mengisi Kebutuhan Hukum Nasional" in Mimbar Hukum No. II Year IV 1993, (Jakarta: al-Hikmah and Islam BITBINBAPERA), p. 2

${ }^{3}$ Amir Syarifuddin, “ Meretas Kebekuan Ijtihad: Isu-Isu Penting Hukum Islam Kontemporer di Indonesia” (Jakarta: Ciputat Press, 2002), p.

${ }^{4}$ Directorate of Sharia Banking, Bank Indonesia. “ Kebijakan Pengembangan Perbankan Syariah”.(Jakarta: 2011), p. 32.

${ }^{5}$ A. Mukti Arto, Praktek Perkara Perdata pada Peradilan Agama,(Yogyakarta: Pustaka Pelajar, 2004).
} 
Paragraph (1): "Sharia banking dispute settlement is carried out by court within the religious court."

Paragraph (2): "in the event that the parties have agreed on a settlement disputes other than those referred to in paragraph (1) dispute settlement shall be carried out in accordance with the contents of the contract."

Paragraph (3): "dispute settlement as referred to in paragraph (2) must not conflict with sharia principles."

However, in this rule there is a contradiction when looking at the explanation of Article 55 paragraph (2) of Law Number 21 of 2008 concerning Sharia Banking above. It creates legal uncertainty which raises several options for dispute resolution mechanisms in the event of a dispute between the Islamic bank and the customer, the provision reads in full.

"What is meant by 'dispute settlement carried out in accordance with the contents of the contract' is the following efforts: a deliberation; $b$. banking mediation; c. through the National Sharia Arbitration Board (Basyarnas) or other arbitration institutions; and / or d. through a court within the General Court."

Based on the explanation above, it raises a dispute settlement option where there is dualism of choice settlement of sharia economic disputes by litigation, because the emergence of article 55 paragraph (2) of Law Number 21 of 2008 including its explanation, it provides space for parties to make choice of places to resolve their sharia banking disputes. Besides through the litigation process in religious courts either through the litigation process in district courts or through non-litigation processes through deliberation, banking mediation and through basyarnas or other arbitration institutions, as long as this is agreed in the contract provided that the dispute settlement mechanism is in accordance with Sharia principles. ${ }^{1}$

In order to maintain legal certainty, the Constitutional Court conducted a judicial review of Article 55 paragraph (2) of Law Number 21 of 2008 because it was contrary to Article 28D paragraph (1) of the 1945 Constitution of the Republic of Indonesia, which in turn confirmed that Islamic economics is the absolute authority of the Religious Courts through the Constitutional Court decision Number 93 / PUU-X / 2012.

The material sources of sharia economic law used in the Religious Courts are contained in Perma number 2 of 2008 concerning the Compilation of Sharia Economic Law (KHES), where this compilation becomes the basis of material law (lex specialist) in the Religious Courts which contains; a). Law Subject and Amwal, b). contract, c). zakat and grants, and d). Islamic accounting.

\subsection{The Role of Religious Courts in Resolving Sharia Economic Disputes During the COVID-19 Pandemic} In principle, sharia economic dispute resolution in religious courts (litigation) is a last resort, if the dispute settlement outside the court is unsuccessful (non-litigation). The settlement outside the court can be pursued by several alternatives (Alternative dispute resolution), such as; consultation, negotiation, mediation, consolidation, or expert judgment, and arbitration.

Dispute resolution according to the sharia economic system is not much different from dispute resolution according to national law. Sharia economic dispute resolution based on Islamic law can be done by means of peace (sulh / islah), arbitration (tahkim) and court (al-Qadla $).^{2}$

During the corona pandemic which was still ongoing for quite a long time to date, it has a significant negative impact on business actors and businesses in this country. This of course can lead to many potential disputes in business agreements between banks as creditors and customers as debtors. In general, the challenges in Islamic banks during the Covid-19 pandemic are liquidity and problematic financing ratios or non-performing financing (NPF).

In the settlement of sharia economic disputes in the Religious Courts, the Supreme Court of the Republic of Indonesia has issued Supreme Court Regulation (PERMA) No. 14 of 2016 concerning Procedures for Settlement of Sharia Economic Cases. This regulation explicitly stipulates that sharia economic cases can be filed by two mechanisms, namely through a small claim court and a lawsuit with an ordinary procedure. ${ }^{3}$

These two mechanisms basically differentiate between the procedures for case examination with the value of material objects of small and large value with the aim that Islamic economic cases can be resolved quickly, simply and at low cost

Settlement of disputes by case examination with simple lawsuit, Article 3 paragraph 2 of Perma No. 14 of 2016 explains that what is meant by case examination with simple procedure / lawsuit is an examination of a sharia

\footnotetext{
${ }^{1}$ Yusna Zaidah. Penyelesaian Sengketa Melalui Peradilan dan Arbitrase Syariah di Indonesia. (Yogyakarta: Aswaja Pressindo, 2015), p. 61

${ }^{2}$ Abdul Manan. Hukum Ekonomi Syariah dalam Perspektif Kewenangan Pengadilan Agama..(Jakarta: Publisher Kencana Prenandamedia Group, 2014), p. 440

${ }^{3}$ See Article 2 PERMA No. 14 of 2016
} 
economic case with a maximum value of IDR 200,000,000.00 (two hundred million rupiah), this provision is also contained in Article 1 of Perma number 2 of 2015 concerning simple lawsuit settlement procedure.

The provisions of this Perma have now been amended by adjusting the current conditions and also revisions through the Supreme Court Regulation (Perma) No. 4 of 2019 concerning Amendments to Perma No. 2 of 2015 concerning Procedures for Settlement of Simple Lawsuits. This is an effort to further optimize the settlement of a simple claim (small claim court) to make it simpler, faster, and less costly.

Several changes in Perma No. 4 of 2019 above is to increase the material value of the simple lawsuit from the maximum provision of Rp. 200,000,000.00 (two hundred million rupiah) to Rp. 500,000,000.00 (five hundred million rupiah), extending the filing of a lawsuit when the plaintiff is outside the jurisdiction of the defendant's domicile. It can use the electronic case administration with a verzet as a resistance to a verdict that is verstek, the existence of bail and execution. Meanwhile, for disputes with a material value above Rp. 500,000,000.00 (five hundred million rupiah) or which do not meet the requirements as a simple lawsuit in accordance with Perma No. 4 of 2019 must be filed with an ordinary lawsuit which refers to the civil procedure law in article 54 of Law number 7 of 1989 concerning the Religious Courts.

In filing a case through a simple or ordinary administrative lawsuit, it can be done through electronic media (e-court). This provision is in Perma No.3 of 2018 concerning Electronic Case Administration. In addition, for technical matters, the trial can also be carried out online using e-litigation as stipulated in Perma No.1 / 2019 concerning Administration of Cases and Trials in Courts Electronically.

Initially, e-court and e-litigation were forms of reform of the Indonesian Supreme Court in the field of information technology in the judicial system in order to lead to a modern justice system. But along with the outbreak of a massive corona virus that has claimed thousands of lives, these two systems play a very important role as an effort to support government programs in an effort to prevent the spread of the Covid 19 outbreak and to keep the judicial process running in order to uphold justice in the midst of the covid 19 disaster siege.

To ensure that sharia economic disputes can be resolved properly by the Religious Courts based on the principle of justice, the Religious Courts have provided 1308 judges who have been certified in sharia economics and formed a special council for Sharia economic cases at the first level, appeal, and cassation.

\subsection{Resolution of Problematic Financing Disputes through Special Treatment}

The Indonesian government has designated COVID-19 as a type of disease that has become a national disaster through Presidential Decree No.12 of 2020 concerning Determination of Non-Natural Disasters for the Spread of Corona Virus Disease 2019 (COVID-19) as a National Disaster. That's why the government always appeal to the citizens regarding the implementation of physical distancing, wearing masks, and doing activities both working, studying and being productive at home.

In order to reduce the economic impact of this disaster, the government through the financial services authority (OJK) issued Regulation of the Financial Services Authority Number 11 / POJK.03 / 2020 concerning National Economic Stimulus as a Policy on the Countercyclical Impact of the Spread of Corona Virus Disease 2019.

In POJK No. 11/2020, it stipulates that conventional commercial banks, including sharia business units, Islamic commercial banks, people's credit banks, Islamic people's finance banks, which carry out business activities conventionally or based on sharia principles, can provide restructuring policies, credit relief, or new fund financing to debtors who are indeed affected by COVID 19. This policy is given only to debtors who have difficulty fulfilling obligations to the Bank because the debtor or debtor's business is affected by the spread of coronavirus disease 2019 (COVID-19) either directly or indirectly in the economic sector, among others tourism, transportation, hospitality, trade, processing, agriculture, and mining.

In establishing the above policies, OJK uses the precautionary principle and conducts self-assessment of all business sectors that submit assistance to the above policies to banks. This is done in order to implement relaxation in order to protect and save business actors and banks themselves. The restructuring is carried out in accordance with the OJK regulations regarding asset valuation, among others by: a.) a reduction in the rate of return (margin, profit sharing, lease, or fee), b.) Extension of the period in fulfilling performance, c.) Reduction in principal arrears, d.) Reduction in arrears of yields, e.) Additional facilities or financing, or f.) Conversion of financing into temporary equity participation.

From a legal perspective, a number of regulations and steps to limit the activities of the entire community were taken by the Government to reduce the spread of COVID-19. This government policy in the end, led to an increase in debtors who were unable to fulfill their achievements / obligations to creditors. One of the reasons that can be used as the basis for his defense of the default claim is the existence of force majeure or overmacht.

In terms of force majeure in an agreement, it is often referred to as an overmacht; act of God coercion, emergency, force majeure, circumstances beyond human ability. ${ }^{1}$ In Indonesia, this provision is regulated in article

\footnotetext{
${ }^{1}$ Munir Fuady, Konsep Hukum Perdata, (Jakarta: PT. Raja Grafindo Persada, 2016), p. 214.
} 
1245 BW, which reads;

"There is no compensation for costs, losses and interest, if due to coercive circumstances or due to an accidental incident, the debtor is prevented from giving or doing something that is required, or because of the same things he has committed an illegal act."

Force majeure in contract law is a situation where a person who is obliged (debtor) is prevented from carrying out his performance due to circumstances or events that are unexpected and cannot be anticipated at the time the agreement was made that issued the obligation, and such circumstances or events cannot legally be accountable to the debtor concerned, while the debtor is not in a state in bad faith. ${ }^{1}$

In the event that a Sharia economic dispute submitted to the Religious Court is related to the reason for force majure, the judge must be careful and thorough in examining the proving value provided by the debtor, this is as regulated in Article $1444 \mathrm{BW}$;

"If a certain item which is the subject of the agreement is destroyed, cannot be traded, or is lost, so that it is not known at all whether the item is still there, then erase the bond, as long as the item is destroyed or lost outside the fault of the debtor and before he is negligent in handing it over. Even if the debtor is negligent in handing over an item while he has not been responsible for unforeseen events, the bond is still terminated if the item will be destroyed in the same manner in the hands of the debtor, if it has been handed over to him. "

The debtor is obliged to prove the unforeseen event, which he promotes. In whatever way an item has been stolen, destroyed or lost, the loss of this item will never free the person who stole the item from his obligation to change the price. "

From the definition and provisions of Burgelijk Weetbok as a source of civil law guided in Indonesia regarding force majure or overmacht above, it can be concluded that there are several requirements attached to an event that is claimed to be a force majure or overmacht, namely; 1.) There is an obstacle to fulfilling obligations, 2.) It is not due to the customer's fault, 3.) It is not caused by a situation that is the customer's risk, 4.) The situation is forcing and beyond the customer's control, and 5.) The situation is not known in advance.

From the requirements above, there are at least three elements that must be proven by the customer, namely; 1.) The condition is real and can be proven, 2.) There is no element of error from the customer, and 3.) The customer can prove that the situation was not foreseeable.

Regarding the COVID epidemic that has spread almost throughout the archipelago, it is necessary to know that of course there will be many business sectors, both companies and MSMEs, which will be affected by the negative economic side of this disaster. If all claim to be a force majure / overmacht then, banks will experience considerable liquidity which are at risk of greater financial chaos because most bank funds are public money that is stored in the form of savings, deposits or other investments.

So as another alternative is in conditions where it is still possible to find a win-win solution to renegotiate by setting it as hardship or in Arabic it is called masyaqqah (difficult situation). Hardship / masyaqqah is an event that has fundamentally been changing the balance of the nature of the agreement / contract which is unpredictable (the principle of rebus sic stantibus). By accepting an event that fundamentally affects the balance of the contract as hardship, of course, it will have legal consequences for the contract made by the parties. This principle is in line with the proposed principles of fiqh which means that harm must be eliminated.

If there is hardship / masyaqqah, then the alternative solutions are as follows: ${ }^{2}$

a) The party who is aggrieved has the right to ask for contract renegotiation to other parties. The request must be submitted immediately, indicating the (legal) basis for the request for renegotiation.

b) A request for renegotiation automatically entitles the aggrieved party to stop executing the contract.

c) If negotiations fail to reach an agreement within a reasonable timeframe, the parties can take it to court.

d) If the court proves the existence of hardship, the court may decide to:

i. Terminate the contract at a fixed date and time; or

ii. Change the contract by restoring the balance.

In an effort to facilitate operations, refer to the POJK regulation Number $11 /$ POJK.03 2020 concerning National Economic Stimulus as a Policy on the Countercyclical Impact of the Spread of Corona Virus Disease 2019, namely with a choice of policies in the form of restructuring, credit relief, or new funding for debtors who are indeed affected by Covid 19. And to help with this condition, the loss caused by Covid 19 can be guaranteed by the government as regulated in Permenkeu number 71 / PMK.08 / 2020 Regarding Guarantee Procedures The government through designated guarantee business entities in the context of implementing the National Economic Recovery Program.

The fundamental difference between force majure / overmacht and hardship / Masaqqah is the result of both,

\footnotetext{
${ }^{1}$ Ibid.

${ }^{2}$ Agus Yudha Hernoko, Hukum Perjanjian (Asas Proporsionalitas dalam Kontrak Komersial), (Jakarta: Kencana, 2010), p. 285.
} 
if force majure / overmacht is proven, at that time the contract / contract will end. Whereas in hardship / Masaqqah, if proven, the contract does not automatically become ends, but can be renegotiated. If it fails, then it will be brought back to court and the judge can terminate the contract by applying the principle of personality / balance.

\section{Conclusion}

Sharia economic dispute resolution is the authority of the Religious Courts since the enactment of Law Number 3 of 2006 concerning Amendments to Law Number 7 of 1989 concerning the Religious Courts, therefore Judges in the Religious Courts must continue to increase their capacity both personally and institutionally. In the midst of the COVID 19 disaster that has hit all over Indonesia, it is possible for a spike in disputes to occur in the economic and business world between banks, especially Islamic banking and their customers. For this reason, the Religious Courts must be able to continue to exist in an effort to resolve sharia economic disputes while remaining alert to the threat of Covid 19 for the health of civil servants and society in general.

The use of technology through e-court and e-litigation plays an important role in resolving sharia economic disputes in the midst of the COVID-19 pandemic, both in administrative processes and in digital trials to prevent the spread of the corona virus in Indonesia. In order to facilitate the process of resolving sharia economic disputes by litigation at the Religious Courts, the Supreme Court of the Republic of Indonesia has issued a Supreme Court Regulation (Perma) No. 4 of 2019 concerning Amendments to Perma Number 2 of 2015 concerning Procedures for Settlement of Simple Lawsuits, in which Sharia economic disputes with a material value of less than Rp. $500,000,000.00$ (five hundred million rupiah) can be made in a simple lawsuit. This is intended so that the dispute resolution process with a nominal value is not too large, it can be resolved more simply, quickly, and at low cost.

Against customer claims in the Religious Courts on the basis of force majure / overmacht, the judge must be careful in assessing the evidence what the debtor does to the three elements of force majure / overmacht, namely; 1.) The condition is real and can be proven, 2.) There is no element of error from the customer, and 3.) The customer can prove that the situation was not foreseeable. If it is still possible to find a middle way of a win-win solution by renegotiating it should be determined as hardship or masyaqqah (difficult situation). This is done for either customers or banks so that the negative economic impacts of the COVID 19 pandemic can be maintained.

The renegotiation can refer to the POJK regulation Number 11/ POJK.03 / 2020 concerning National Economic Stimulus as a Policy on the Countercyclical Impact of the Spread of Corona Virus Disease 2019, by providing policy options in the form of restructuring, credit relief, or new fund financing for debtors who are indeed affected by Covid 19. And to help with this condition, losses caused by Covid 19 can take advantage of guarantees by the government as regulated in Permenkeu number 71 / PMK.08 / 2020 concerning Government Guarantee Procedures through Designated Guarantee Business Entities in the Context of Implementing the National Economic Recovery Program.

\section{REFERENCES}

Abdul Halim, (2000). Peradilan Agama Dalam Politik Hukum di Indonesia dari Konservatif menuju Konfigurasi Demokrasi-Responsif. Jakarta: Raja Grafindo Persada.

Abdul Manan, (2014). Hukum Ekonomi Syariah dalam Perspektif Kewenangan Pengadilan Agama. Jakarta: Kencana Prenandamedia Group, 2014.

Abdullah Abdul Husain at-Tariqi, (2004). Ekonomi Islam Prinsip, Dasar dan Tujuan. Jakarta: Magistra Insania Press.

Amir Syarifuddin, (2002). Meretas Kebekuan Ijtihad: Isu-Isu Penting Hukum Islam Kontemporer di Indonesia. Jakarta: Ciputat Press.

A. Mukti Arto, (2001). Mencari Keadilan. Yogyakarta: Pustaka Pelajar, 2001.

................., (2004). Praktek perkara Perdata pada Peradilan Agama. Yogyakarta: Pustaka Pelajar.

Agus Yudha Hernoko, (2010). Hukum Perjanjian (Asas Proporsionalitas dalam Kontrak Komersial). Jakarta: Kencana.

C.S.T Kansil dan Christine S.T. Kansil, (2008). Hukum Tata Negara Republik Indonesia. Jakarta: Rineka Cipta.

Direktorat Perbankan Syariah Bank Indonesia, (2001). Kebijakan Pengembangan Perbankan Syariah. Jakarta.

MA. Mannan, The Making of Islamic Economic Society (Cyprus: International Association of Islamic Bank Cairo \& Institute for Islamic Banking and Economic, 1984).

M. Nur Rianto Al Arif, S.E., M.Si, Teori Ekonomi Islam, (Jakarta: ALFABETA, 2010), cet ke I.

M. Umar Chapra, The Future of Economies: an Islamic Prespektive, (Jakarta: SEBI, 2000).

Munir Fuady, Konsep Hukum Perdata, (Jakarta: PT. Raja Grafindo Persada, 2016).

Yusna Zaidah. Penyelesaian Sengketa Melalui Peradilan dan Arbitrase Syariah di Indonesia. (Yogyakarta: Aswaja Pressindo, 2015).

https://republika.co.id/berita/q9tijc320/perbankan-syariah-hadapi-covid19tantangan-dan-solusi accessed on August 27th 2020. 